\title{
PENGEMBANGAN MODUL ELEKTRONIK FISIKA BERBAHASA INGGRIS UNTUK PEMBELAJARAN BERBASIS KTSP PADA SISWA KELAS X INTERNASIONAL SMAN KOTA PADANG
}

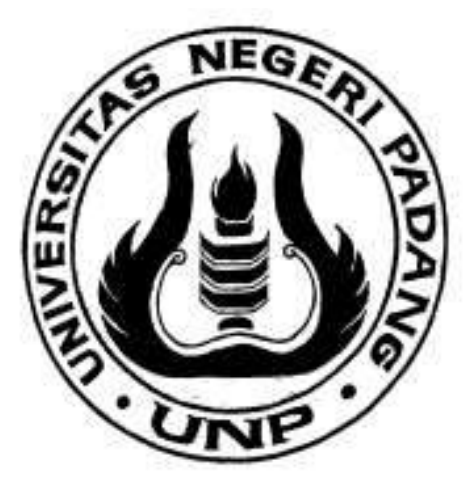

Oleh

ASRIZAL ZULHENDRI KAMUS

Disampaikan Pada Seminar Nasional dan Rapat Tahunan BKS - PTN Wilayah Indonesia Barat Bidang Ilmu MIPA Tanggal 04-05 Mei Tahun 2009 di FMIPA Universitas Syiah Kuala Banda Aceh 


\title{
PENGEMBANGAN MODUL ELEKTRONIK FISIKA BERBAHASA INGGRIS UNTUK PEMBELAJARAN BERBASIS KTSP PADA SISWA KELAS X R-SMA-BI KOTA PADANG
}

\author{
Asrizal \\ Jurusan Fisika FMIPA Universitas Negeri Padang, email asrizal_unp@yahoo.com
}

\begin{abstract}
Objective of research is to develop a Physics interactive electronic as a learning source for students in international school. Research method that used to create and to test validity and effectivity of modul is research and development or R\&D. Instruments to collect the data in this research consist of into two parts, those are validation evaluation sheet of technical assistant and learning result test of students. The data was analyzed by three methods, those are: graph method, descriptive analysis, and correlation compare mean test. There are three main results of this research, those are: 1). Physics interactive electronic module in English is created in learning CD form consist of five modules, 2). Physics electronic module in English that created has good validity in layout, curriculum content, language matching, usage of phenomena, and complicating of multimedia with average value was 86.36 , and 3). Physics interactive learning module in English was effective used in learning base on KTSP.
\end{abstract}

Kata Kunci : electronic module, KTSP base learning, international school, validity, effectiviness

\section{PENDAHULUAN}

Pada saat ini era globalisasi sudah memasuki dunia pendidikan, sehingga menuntut sekolah untuk mampu melakukan berbagai upaya untuk menciptakan lulusan yang berdaya saing global (Eddy, K: 2006). Arah dasar pendidikan dalam kultur global harus mampu mencakup aspek pengetahuan, keterampilan, pembentukan karakter, dan internalisiasi nilai-nilai dasar hidup manusia (Sunny: 2006). Dengan dasar ini pemerintah melalui Derektorat Pendidikan Menengah Umum membuat program sekolah bertaraf internasional (SBI). Menurut UU nomor 20 tahun 2003, pasal 50 ayat 3 "Pemerintah dan/ atau Pemerintah daerah menyelenggarakan sekurangkurangnya satu satuan pendidikan yang bertaraf internasional”. Sebagai implementasi dari UU ini telah dicobakan SBI di SMA konvensional. 
SBI adalah sekolah yang menggunakan kurikulum nasional dengan melakukan inovasi-inovasi di bidang pengelolaan sekolah dan inovasi di bidang proses pembelajaran serta didukung sarana yang memadai sesuai perkembangan teknologi untuk menciptakan lulusan yang mampu bersaing dengan lulusan sekolah terbaik lainnya di dunia. Dengan kata lain SBI merupakan sekolah yang melakukan proses peningkatan kualitas yang berkesinambungan sehingga menghasilkan lulusan yang berdaya saing tinggi.

Ada beberapa alasan pentingnya program SBI di Indonesia. Pendidikan di Indonesia dituntut untuk menghasilkan sumber daya manusia unggul di segala bidang, mampu bersaing di dunia kerja, dan memiliki jiwa kebangsaan yang tinggi. Keluaran yang diinginkan dari sekolah menengah tidak hanya punya keunggulan di bidang pengetahuan dan teknologi tetapi juga punya jiwa kebangsaan yang tinggi, sehingga dimanapun berada selalu memberikan karya terbaik bagi bangsa dan negaranya. Karena itu ada tiga tujuan program SBI yaitu: meningkatkan kompetensi lulusan, mengelimininir keinginan sekolah ke luar negeri, dan mencegah pengikisan identitas bangsa Indonesia yang berjiwa kebangsaan (Eddy, K: 2006).

Salah-satu upaya yang telah dilakukan untuk mengimpelentasikan UU ini adalah membentuk rintisan sekolah menengah atas bertaraf internasional (R-SMA-BI). Pada R-SMA-BI, guru mampu melaksanakan pembelajaran dalam bahasa Inggris secara efektif dan mampu menggunakan media atau sumber belajar berbasis TIK dalam pembelajaran (Sungkowo: 2008).

Pemerintah daerah Sumatera Barat melalui Dinas Pendidikan merespon secara antusias amanat UU nomor 20 tahun 2003 ini. Pada tahap pertama, ada lima buah SMAN di Sumatera Barat yang terlibat dalam program rintisan ini yaitu : SMAN 1 dan 10 Padang; SMAN 1 Padang Panjang, Bukit Tinggi, dan Lubuk Sikaping (Admin: 2006). Pada tahap selanjutnya direncanakan jumlah R-SMA-BI di Sumatera Barat akan bertambah karena tingginya antusias dan motivasi.

Dalam prakteknya guru bidang studi mengajarkan materinya berbahasa Inggris menggunakan sumber belajar berbasis ICT. Dalam merealisaikan tujuan ini telah dilakukan beberapa upaya seperti melakukan tes toefl, melakukan pelatihan bahasa Inggris di balai bahasa, dan melakukan workshop tentang R-SMA-BI. Namun dalam 
pelaksanaan pelatihan masih ditemukan dua kendala utama yaitu : instruktur yang melatih guru bidang studi kurang memahami tentang materi fisika dan guru bidang studi fisika kurang lancar mengajar fisika berbahasa Inggris. Akibatnya tujuan dan pesan yang ingin disampaikan kurang tercapai.

Berdasarkan hasil pengamatan peneliti selama kegiatan in house training pada R-SMA-BI ternyata guru fisika di SMAN Sumatera Barat belum mampu menerapkan bahasa Inggris secara efektif dalam pembelajaran. Permasalahan utama yang ditemukan yaitu guru mengalami kesulitan dalam menggunakan bahasa Inggris sebagai pengantar dan ICT dalam pembelajaran fisika.

Sebagai akibat dari permasalahan ini adalah pesan materi baik berupa pengertian, konsep, hukum, teori dan sebagainya yang disampaikan guru berbahasa Inggris kurang dapat diterima oleh siswa dengan baik. Komunikasi akan berjalan dengan baik dan lancar apabila terdapat kesesuaian antara penyampai pesan dan penerima pesan. Untuk itu diperlukan suatu media yang dapat digunakan untuk membantu menyampaikan informasi dari guru kepada siswa sebagai penerima pesan.

Salah satu alternatif untuk mengatasi permasalahan ini adalah mengembangkan suatu bahan ajar yang berkualitas yang dapat digunakan sebagai sumber belajar bagi siswa untuk mengkontruksi pengetahuan fisika berbahasa Inggris. Sesuai dengan kemajuan ilmu pengetahuan dan teknologi bahan ajar elektronik berbasis multimedia interaktif diperkirakan merupakan suatu alternatif terbaik sebagai sumber belajar bagi siswa dan sebagai media dalam pembelajaran fisika berbasis KTSP berbahasa Inggris.

Penyediaan modul elektronika interaktif memberikan keuntungan dalam proses pembelajaran baik bagi guru maupun siswa. Sekurang-kurangnya ada tiga tujuan pengguaan modul dalam pembelajaran yaitu: memperjelas dan mempermudah penyajian pesan; mengatasi keterbatasan waktu, ruang, dan daya indra; serta meningkatkan motivasi dan mengembangkan kemampuan berinteraksi dengan sumber belajar (Bambang, S: 2007).

Modul elektronik fisika digunakan dalam pembelajaran berbasis KTSP. Dalam pembelajaran, tugas guru yang paling utama adalah mengkondisikan lingkungan agar menunjang terjadinya perubahan perilaku bagi peserta didik. Menurut Mulyasa (2006) 
pada umumnya pelaksanaan pembelajaran berbasis KTSP mencakup tiga hal yaitu: pretest, pembentukan kompetensi, dan postest.

Dengan dasar ini peneliti tertarik untuk mengembangkan modul elektronik interaktif untuk pembelajaran fisika berbahasa Inggris. Tujuan dari penelitian ini yaitu: menghasilkan modul elektronik interaktif fisika berbahasa Inggris yang memiliki deskripsi yang baik dan validitas yang tinggi, serta menentukan efektivitas penggunaan modul dalam pembelajaran berbasis KTSP.

\section{METODE PENELITIAN}

Jenis penelitian yang akan dilakukan adalah penelitian dan pengembangan (Research and Development/ $R \& D$ ). Sugiyono (2006) mengemukakan pengertian R\&D adalah metode penelitian yang digunakan untuk menghasilkan produk tertentu, dan menguji keefektifan produk tersebut. Disisi lain menurut Nana, S.S (2006) R\&D adalah suatu proses atau langkah-langkah untuk mengembangkan suatu produk baru atau menyempurnakan produk yang telah ada, yang dapat dipertanggung jawabkan. Produk yang dihasilkan merupakan bagian yang penting pada pada penelitian ini.

Dalam mengembangkan produk penelitian dan menguji validitas dan efektivitas ditempuh enam langkah kegiatan. Langkah-langkah penelitian yang dilakukan meliputi: mengenali potensi dan masalah, mengumpulkan informasi, mendesain produk, memvalidasi desain, memperbaiki desain, dan melakukan uji coba produk dalam skala terbatas.

Untuk menentukan validitas ditentukan melalui penilaian tenaga ahli terhadap produk. Disisi lain untuk menentukan efektivitas dilakukan dengan cara membandingkan keadaan sebelum dan keadaan sesudah (before-after) Model eksperimen ini diperlihatkan seperti pada Gambar 1:

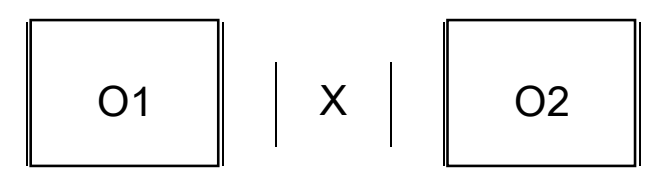

Gambar 1. Desain Eksperimen Sebelum - Sesudah

Disini $\mathrm{O}_{1}$ adalah nilai sebelum perlakuan, sedangkan $\mathrm{O}_{2}$ adalah nilai sesudah perlakuan. Eksperimen dilakukan dengan membandingkan hasil observasi $\mathrm{O}_{1}$ dan $\mathrm{O}_{2}$. 
Efektifitas pemberian perlakuan dapat diukur dengan cara membandingkan nilai $\mathrm{O}_{2}$ dengan $\mathrm{O}_{1}$. Bila nilai $\mathrm{O}_{2}$ lebih besar dari pada $\mathrm{O}_{1}$, maka dapat dikatakan perlakuan tersebut efektif.

\section{HASIL DAN PEMBAHASAN}

\section{Produk Modul Elektronik Interaktif Fisika Berbahasa Inggris}

Modul elektronik interaktif Fisika berbahasa Inggris dibuat sesuai dengan rancangan yang telah disusun. Halaman depan dari modul elektronik diperlihatkan seperti pada Gambar 2.

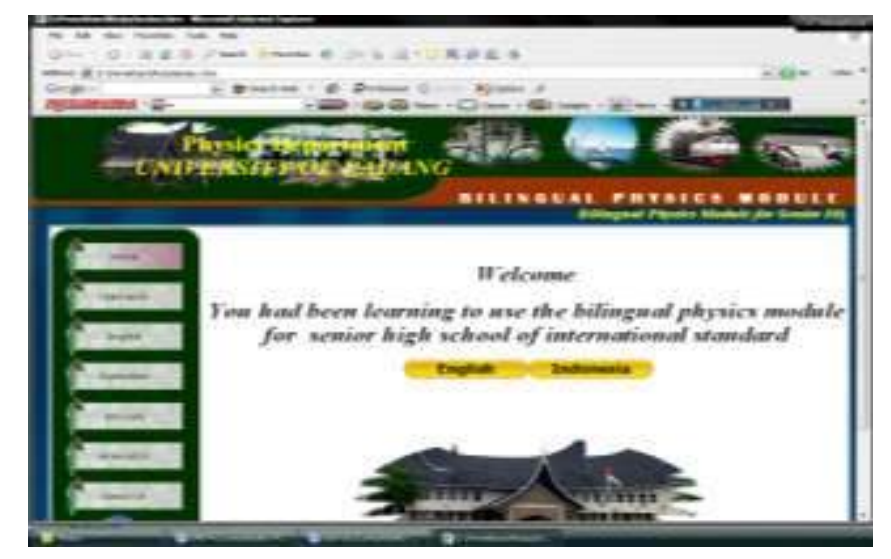

Gambar 2. Halaman Depan Modul Elektronik Fisika

Pada halaman depan modul elektronik interaktif Fisika berbahasa Inggris terdapat identitas, judul, ucapan selamat datang dan pilihan bahasa. Pada bagian sebelah kiri dari halaman depan modul elektronik interaktif terdapat tujuh menu pilihan yaitu menu home untuk menampilkan halaman depan, menu Indonesia untuk menampilkan halaman utama dari modul berbahasa Indonesia, menu English untuk menampilkan halaman utama dari modul berbahasa Inggris, menu Guidelines berisi panduan penggunaan modul, menu glossary untuk memperlihatkan daftar kosa kata dan istilah Fisika dalam bahasa Indonesia dan Inggris, menu animation untuk melihat animasi Fisika setiap topik pembelajaran, dan menu about us berisi tim penyusun modul. Pemakai diberikan kemudahan dan kebebasan memilih salah satu dari menu sesuai keinginan. Jika pemakai memilih menu English maka ditampilkan halaman utama dari modul berbahasa Inggris seperti diperlihatkan Gambar 3. 


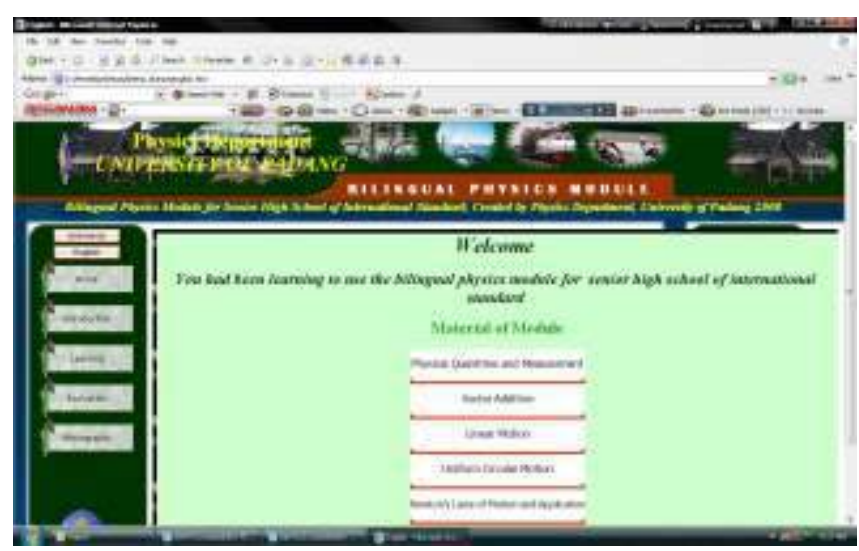

Gambar 3. Menu Utama Modul Fisika Berbahasa Inggris

Menu utama modul berbahasa Inggris menampilkan lima pilihan materi dari modul yaitu physical quantities and measurement, vector addition, linear motion, uniform circular motion, dan Newton's laws of motion and application. Pada tampilan sebelah kiri terdapat tujuh menu pilihan masing-masing adalah Indonesia, English, Home, Introduction, Learning, Evaluation, dan Bibliography. Cara yang sama dapat dilakukan untuk menu-menu pilihan lainnya.

\section{Validitas Modul Belajar Elektronik Interaktif}

Validasi terhadap produk penelitian berupa modul elektronik interaktif Fisika berbahasa Inggris dilakukan untuk mengetahui kesahihan produk yang dihasilkan secara pemikiran rasional. Validasi terhadap produk dilakukan terhadap 12 orang tenaga ahli yang terdiri dari 2 orang dosen bahasa Inggris untuk melihat kesesuaian modul dari segi bahasa, 6 orang guru fisika Sekolah Menengah Atas Negeri, dan 4 orang dosen fisika yang membina mata kuliah fisika dasar dan media pembelajaran.

Metode yang digunakan dalam memvalidasi produk adalah dengan memberikan modul elektronik dan format penilaian validasi. Tenaga ahli membahas tentang modul elektronik interaktif fisika berbahasa Inggris yang telah diberikan, dan melakukan penilaian terhadap produk dengan menggunakan instrumen penilaian validitas produk.

Berdasarkan instrumen penilaian validitas modul elektronik interaktif fisika berbahasa Inggris dilakukan analisis terhadap lima kategori yaitu tampilan modul elektronil interaktif fisika, konten modul elektronik interaktif fisika, kesesuaian dengan bahasa dan bidang ilmu fisika, penggunaan fenomena fisika di lingkungan, dan kelengkapan interaktif. 
Kategori tampilan modul elektronik interaktif fisika terdiri dari delapan indikator yaitu tampilan menu utama pada modul elektronik interaktif fisika, jumlah pilihan menu utama yang dikembangkan pada modul elektronik interaktif fisika, kelengkapan tampilan pada menu utama pada modul elektronik interaktif fisika, tata letak menu pilihan pada modul elektronik interaktif fisika, isi tampilan setiap menu pilihan, daya tarik tampilan menu utama, penggunaan font, dan ilustrasi, grafis, gambar, foto. Berdasarkan data yang diperoleh dari instrumen validitas dilakukan analisis melalui penskoran terhadap masing-masing indikator. Indikator setiap kategori ditempatkan pada sumbu X, sedangkan skor dan nilai ditempatkan pada sumbu Y pada sistem koordnat XY. Hasil plot ditampilkan pada Gambar 4.

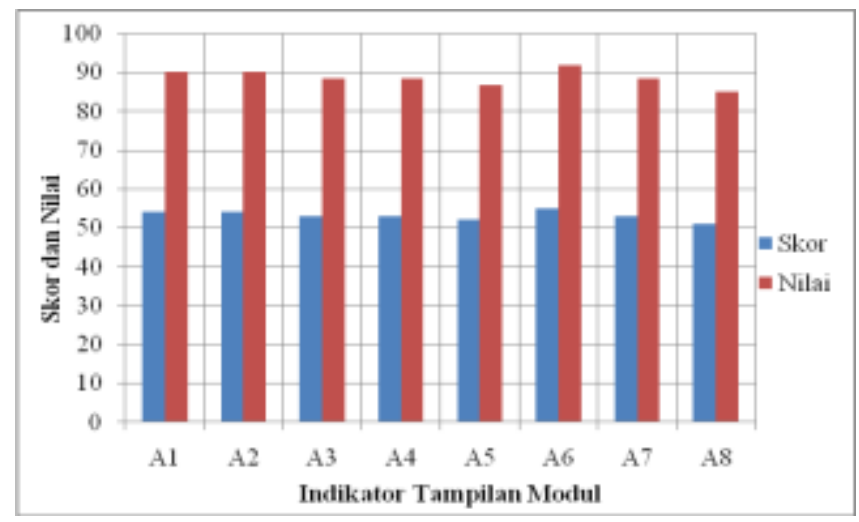

Gambar 4. Skor dan Nilai Dari Kategori Tampilan Modul

Berdasarkan Gambar 4, dapat dijelaskan bahwa skor dan nilai tampilan menu utama pada modul elektronik interaktif fisika masing-masing 54 dan 90; skor dan nilai jumlah pilihan menu utama yang dikembangkan pada modul elektronik interaktif fisika masing-masing 54 dan 90; skor dan nilai kelengkapan tampilan pada menu utama pada modul elektronik interaktif fisika masing-masing 53 dan 88; skor dan nilai tata letak menu pilihan pada modul elektronik interaktif fisika masing-masing 53 dan 88; skor dan nilai isi tampilan setiap menu pilihan masing-masing 52 dan 87; skor dan nilai daya tarik tampilan menu utama masing-masing 55 dan 95; skor dan nilai penggunaan font masing-masing 53 dan 88; skor dan nilai ilustrasi, grafis, gambar, foto masing-masing 51 dan 85 . Pada kategori tampilan modul elektronik interaktif fisika skor berkisar antara 51 sampai 55, sedangkan nilai berkisar antara 85 sampai 95. 
Kedelapan indikator tampilan modul elektronik interaktif fisika memiliki skor dan nilai mendekati sama dan dapat dinyatakan sangat baik.

Dari skor dan nilai kedelapan indikator yang terdapat pada kategori dapat ditentukan skor dan nilai rata-rata dari kategori tersebut. Berdasarkan data didapatkan skor dan nilai rata-rata pada kategori ini masing-masing 53,13 dan 88,54. Skor dan nilai ini menunjukkan bahasa tampilan modul elektronik interaktif fisika sangat baik.

Melalui cara yang sama dapat pula ditentukan skor, nilai, dan validitas nilai dari empat kategori lain yaitu: konten modul elektronik interaktif fisika, kesesuaian dengan bahasa dan bidang ilmu fisika, penggunaan fenomena fisika di lingkungan, dan kelengkapan interaktif. Berdasarkan skor dan nilai rata-rata setiap kategori di plot grafik dengan skor dan nilai rata-rata pada sumbu $\mathrm{X}$ dan kategori yang dinilai pada sumbu Y. Hasil plot data diperlihatkan pada Gambar 5.

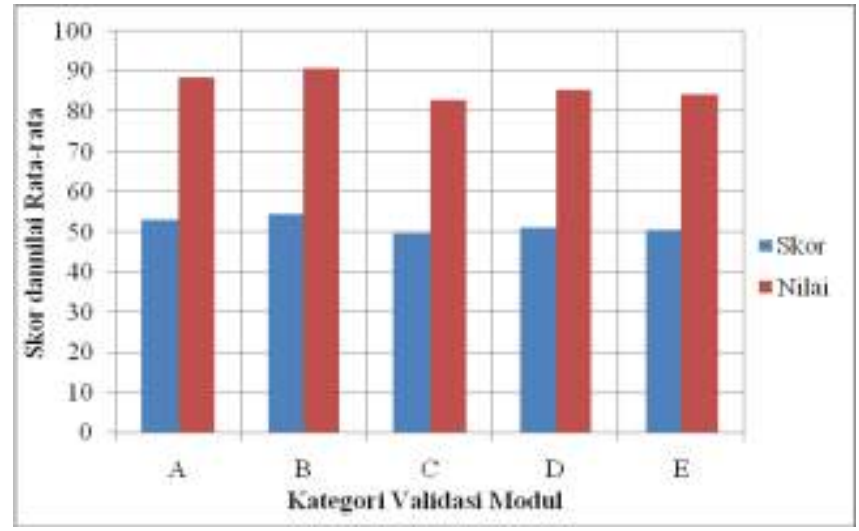

Gambar 5. Skor dan Nilai Rata-Rata Setiap Kategori Validasi Modul

Gambar 5 memperlihatkan skor dan nilai rata-rata kategori tampilan menu utama pada modul masing-masing 53,13 dan 88,54; skor dan nilai rata-rata konten modul elektronik interaktif fisika masing-masing 54,40 dan 90,67; skor dan nilai ratarata kesesuaian dengan bahasa dan bidang ilmu fisika masing-masing 49,80 dan 83,00; skor dan nilai rata-rata penggunaan fenomena fisika di lingkungan masing-masing 51,25 dan 85,42; serta skor dan nilai rata-rata kelengkapan interaktif masing-masing 50,50 dan 84,17 . Secara umum skor rata-rata kelima kategori berkisar antara 49,80 dan 54,40 , serta nilai rata-rata berkisar antara 83,00 dan 90,67 yang menyatakan bahwa setiap kategori sangat baik. Dengan demikian dapat disimpulkan bahwa produk modul belajar elektronik interaktif fisika secara pemikiran rasional adalah valid. 


\section{Efektivitas Penggunaan Modul Elektronik Interaktif}

Efektifitas penggunaan modul elektronik interaktif fisika berbahasa Inggris dapat dilihat dari hasil penerapan modul dalam pembelajaran berbasis KTSP pada skala terbatas. Uji coba penggunaan produk dilakukan di kelas X Internasional SMAN 1 Padang. Tes awal dilakukan terhadap siswa sebelum penggunaan modul dalam pembelajaran berbasis KTSP. Setelah perlakukan diberikan tes akhir.

Melalui analisis terhadap hasil belajar pada tes awal didapatkan parameter statistik deskriptif yaitu: nilai rata-rata 34,40; standar deviasi 11,08, varians 122,67, nilai minimum 16,00 dan nilai maksimum 60,00. Disisi lain nilai parameter statistik deskriptif untuk tes akhir didapatkan nilai rata-rata 68,32; standar deviasi 17,96; varians 322,56; nilai terendah 28,00 dan nilai tertinggi 92,00. Secara umum dari hasil ini dapat dikatakan nilai hasil belajar fisika setelah diberikan perlakuan lebih tinggi dari sebelum diberikan perlakuan.

Efektivitas penggunaan modul elektronik Fisika ditentukan melalui uji t berkorelasi. Nilai t ditentukan dari parameter statistik deskriptif tes awal dan tes akhir serta koefisien korelasi dari kedua tes tersebut. Melalui uji korelasi antara hasil tes akhir dengan tes awal didapatkan koefisien korelasi sebesar 0,428. Dengan menggunakan analisis t-test berkorelasi didapatkan nilai $\mathrm{t}_{\mathrm{h}}=10,24$. Untuk nilai $\alpha=$ 0,05 , derajat kebebasan 48 diketahui nilai $t_{t}=2,00$. Berarti nilai $t_{h}>t_{t}$ sehingga Ho untuk hipotesis kerja ditolak. Hasil ini menunjukkan terdapat perbedaan yang berarti hasil belajar siswa antara setelah dan sebelum perlakuan. Dengan demikian dapat disimpulkan bahwa penggunaan modul elektronik fisika berbahasa Inggris efektif dalam pembelajaran berbasis KTSP di SMAN 1 Padang.

Berdasarkan hasil analisis yang telah dilakukan dapat dikemukakan bahwa tujuan penelitian yang ditetapkan telah dapat dicapai. Pertama, telah dihasilkan modul belajar elektronik interaktif fisika berbahasa Inggris untuk implementasi pembelajaran berbasis KTSP berbentuk CD pembelajaran. Kedua, modul elektronik interaktif fisika berbahasa Inggris valid dari segi penampilan, konten, kesesuaian bahasa, penggunaan fenomena dan kelengkapan interaktif. Ketiga, modul elektronik interaktif fisika 
interaktif berbahasa Inggris efektif digunakan sebagai sumber belajar bagi siswa untuk implementasi pembelajaran berbasis KTSP.

Namun desain modul elektronik interaktif fisika berbahasa Inggris dan penerapannya dalam pembelajaran berbasis KTSP masih mengalami beberapa keterbatasan dan kelemahan. Keterbatasan dari segi desain terletak pada pemberian efek suara yang masih menoton dan rendahnya tingkat interaktif modul. Kelemahan penggunaan modul dalam pembelajaran terletak pada fasilitas pendukung. Jumlah komputer untuk mendukung proses pembelajaran masih terbatas sehingga siswa kurang bisa memanfaat komputer untuk mempelajari modul elektronik Fisika.

Seharusnya keberadaan modul belajar elektronik interaktif ini dapat mengatasi masalah keterbatasan waktu jika didukung dengan fasilitas yang memadai. Modul dapat berperan sebagai sumber belajar dan media dalam pembelajaran. Siswa akan terbantu untuk memahami ide dan memperoleh informasi yang sangat kompleks. Disamping itu, sumber belajar dalam bentuk CD pembelajaran ini juga dapat menjembatani keterbatasan waktu, ukuran, dan ruangan (Tian Belawati: 2003).

\section{DAFTAR PUSTAKA}

Admin, (2006). SMAN Internasional Mencari bentuk. Situs Dinas Pendidikan Kota Malang, Rubrik Pengembangan Pendidikan.

Bambang, S, (2007). Materi Sosialisasi dan pelatihan Kurikulum Tingkat satuan Pendidikan (KTSP) SMA. Departemen Pendidikan Nasional, Jakarta.

Depdiknas, (2006). Pengembangan Bahan Ajar. Ktsp.Jardiknas.org/download/ktspsmk/11.ppt

Eddy, K, (2006). SNBI Suatu Alternatif di Persaingan Global. Prasasti Online, WordPress.

Mulyasa, (2006). Kurikulum Tingkat Satuan Pendidikan: Sebuah Panduan Praktis. PT Remaja Rosdakarya, Bandung

Nana Syaodih Sukmadinata, (2006). Metode Penelitian Pendidikan. PT. Remaja Rosdakarya, Bandung.

Sugiyono, (2006). Metode Penelitian Pendidikan: Pendekatan Kuantitatif, Kualitatif, dan $R \& D$. Alfabeta, Bandung

Sungkowo, (2008). Panduan Penyelenggaraan Program Rintisan SMA Bertaraf Internasional (R-SMA-BI). Departemen Pendidikan Nasional Direktorat Jenderal Manajemen Pendidikan Dasar dan Menengah Direktorat Pembinaan Sekolah Menengah Atas. 